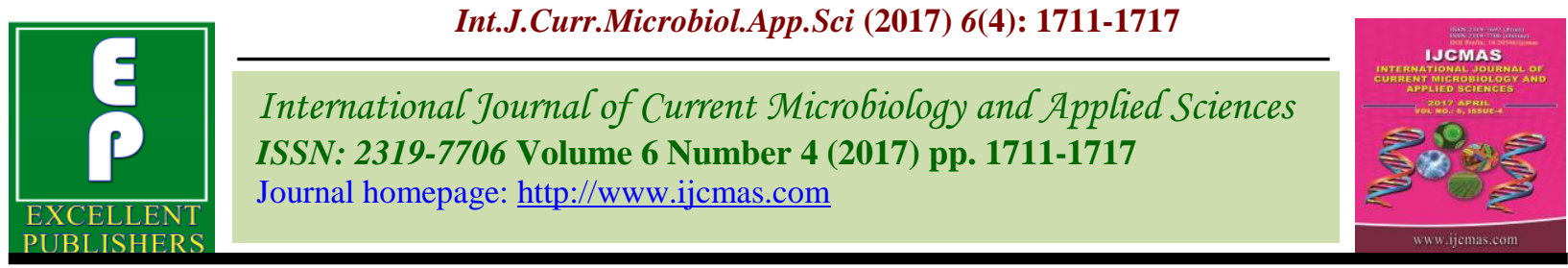

Review Article

https://doi.org/10.20546/ijcmas.2017.604.205

\title{
Effect of Various Drying Methods on Drying Time and Quality of Pomegranate (Punica granatum L.) Arils
}

\author{
Monalisa Hota*, D.S. Dahiya and Sonu Kumar \\ Department of Horticulture, Chaudhary Charan Singh Haryana Agricultural University, \\ Hisar, Haryana, 125 004, India \\ *Corresponding author
}

\begin{tabular}{|c|c|}
\hline & A B S T R A C T \\
\hline $\begin{array}{l}\text { K e y w o r d s } \\
\text { Anardana, } \\
\text { Aril, } \\
\text { Pomegranate, } \\
\text { Drying, } \\
\text { Quality. }\end{array}$ & $\begin{array}{l}\text { The fruit of pomegranate (Punica granatumL.) is consumed fresh or it can be processed } \\
\text { into juice, syrup, jam (anar rub), wine or anardana. Commercialization of process } \\
\text { technology and pomegranate products in market is very important to improve economy. } \\
\text { The seed are dried along with pulp i.e. aril, which constitutes the product "anardana". The } \\
\text { anardana has good keeping qualities along with certain advantages such as flavour and } \\
\text { stability at room temperature over a long storage period, protection from enzymatic and } \\
\text { oxidative spoilage, light weight for transport beside elimination of costly refrigeration. }\end{array}$ \\
\hline Article Info & $\begin{array}{l}\text { Dried pomegranate (anardana) finds its utility as a condiment in the acidification of } \\
\text { chutneys and adds a peculiar taste to some famous north Indian delicacies. The traditional }\end{array}$ \\
\hline $\begin{array}{l}\text { Accepted: } \\
15 \text { March } 2017 \\
\text { Available Online: } \\
10 \text { April } 2017\end{array}$ & $\begin{array}{l}\text { healers used a number of formulations of anardana as ayurvedic medicines in the treatment } \\
\text { of dysentery, diarrhoea, stomachache, inflammations, hymenoletidosis, dyspepsia, } \\
\text { bronchitis and cardiac problem. In this review we discussed about various effect of drying } \\
\text { methods on quality of pomegranate arils. }\end{array}$ \\
\hline
\end{tabular}

\section{Introduction}

Pomegranate (Punica granatum L.) is a wellknown table fruit of tropical and subtropical regions of the world. The fruit of pomegranate is consumed fresh or it can be processed into juice, syrup, jam (anar rub), wine or anardana. The juice is valued for its medicinal properties mainly for leprosy patients. Juice is also used as cooling ingredient refrigerant of mixtures and some medicines for dyspepsia. The bark and rind of the fruits and seeds are used as astringent in cases of diarrhoea and dysentery. In peninsular India, a kind of wine is prepared from pomegranate juice which is considered superior to grape vine. The sweet types of pomegranate are said to be mildly laxative, while the less sweet types are believed to be good in inflammation of stomach and in heart pain. The seeds are considered to be stomachic and the pulp cardiac and stomachic. Despite all these advantages, the consumption of pomegranate seeds is limited to the crop season due to problems of preservation (Defilippi et al., 2006). Drying is the most widely employed method for preserving food materials, which is based on reduction of the water activity values through moisture removal to achieve physicochemical and microbiological stability (Gorjian et al., 2011). Dried products have almost unlimited shelf-life in proper packages and substantially lower transportation, handling and storage 
costs compared to foodstuffs produced with other preservation methods (Ertekin and Yaldiz, 2010).

The seed of pomegranate are dried along with pulp i.e. aril, which constitutes the product "anardana". The anardana has good keeping qualities along with certain advantages such as flavour and stability at room temperature over a long storage period, protection from enzymatic and oxidative spoilage, light weight for transport beside elimination of costly refrigeration. Dried pomegranate (anardana) finds its utility as a condiment in the acidification of chutneys and adds a peculiar taste to some famous north Indian delicacies. The traditional healers used a number of formulations of anardana as ayurvedic medicines in the treatment of dysentery, diarrhoea, stomachache, inflammations, hymenoletidosis, dyspepsia, bronchitis and cardiac problem. During drying many changes take place; structural and physic-chemical modifications affect the final product quality, and the quality aspects involved in dry conversion in relation to the quality of fresh products and applied drying techniques. In this review discussion were made about various effect of drying methods on quality of pomegranate arils.

\section{Effect of drying methods on drying time}

Singh and Kingsly (2008) conducted an experiment on effect of convective drying on quality of anardana. Drying temperature is optimized in this study for getting better end product with quality retention during storage. The arils were dehydrated at $50^{\circ}, 55^{\circ}, 60^{\circ} \mathrm{C}$ and packed in polyethylene bags. In all the drying temperature selected, higher temperature had shorter drying time. Minimum time was recorded in case of cabinet drying at $60^{\circ} \mathrm{C}$ followed by $55^{\circ} \mathrm{C}$. Aggarwal et al., (2010) conduct a study on drying of various hill crops (Pomegranate, Ginger, Turmeric and
Red chili) in open sun, oven and solar dryer for quality comparison. The dried products were tested in the post harvest technology laboratory for value addition. The time taken to dry the pomegranate was $21 \mathrm{~h}$ in solar dryer and the quality of the product is better as compared to other drying methods.

Santra and Jain (2012) found that the initial moisture content of pomegranate arils were in the range of 377.09 to 442.68 percent $(\mathrm{db})$ which reduced to 5.69 to 9.62 percent (db) after $26.5,17.5,14$ and $7.5 \mathrm{~h}$ for drying air temperature of $45,50,55$ and $60^{\circ} \mathrm{C}$, respectively. The drying time was reduced to $17.5 \mathrm{~h}$ when the drying air temperature was increased to $50^{\circ} \mathrm{C}$, showing 33.96 percent reduction in time. When the drying temperature further increased to $55^{\circ} \mathrm{C}$, the drying time for same moisture reduction was decreased to $14 \mathrm{~h}$ showing 47.16 percent for the reduction in time. Finally for $60^{\circ} \mathrm{C}$, the drying time was found to be $7.5 \mathrm{~h}$ which was $71.69,57.14$ and 46 percent less than 45, 50 and $55^{\circ} \mathrm{C}$ drying air temperature, respectively.

Bhat et al., (2014) conducted a study on the effect of drying methods and packaging on shelf life of dried wild pomegranate arils. Pre-treated arils were dried in different drying modes like mechanical cabinet dryer $\left(62 \pm 2^{\circ} \mathrm{C}\right)$, solar cabinet dryer $\left(50-55^{\circ} \mathrm{C}\right)$ and open sun (18$24^{\circ} \mathrm{C}$ ). Mechanical cabinet dryer was found to be most suitable on the basis of faster drying rate, physico-chemical and sensory characteristics. Sample dried in mechanical cabinet dryer took $10 \mathrm{~h}$ time to dry with lowest moisture content (9\%) and highest total soluble solids $\left(39.6^{\circ}\right.$ Brix $)$.

Yilmaz et al., (2015) found that fastest drying of pomegranate leather was completed in vacuum dryer followed by cabinet dryer and open air drying. The drying process in cabinet dryer was completed in $35 \mathrm{~min}$ at $70^{\circ} \mathrm{C}$ for the samples at $1 \mathrm{~mm}$ and $60 \mathrm{~min}$ and $65 \mathrm{~min}$ for 2 
and $3 \mathrm{~mm}$ samples, respectively, at the same temperature level. The drying time significantly increased together with the lowering of drying temperature. Drying process was completed in $150 \mathrm{~min}$ and in 290 min for the $3 \mathrm{~mm}$ samples at $60^{\circ} \mathrm{C}$ and $50^{\circ} \mathrm{C}$ temperature levels, respectively.

\section{Effect of drying methods on dry aril} recovery $(\%)$

Recovery percent of pomegranate arils were maximum in sun drying (32.9\%) followed by solar cabinet dryer (32.4\%) and mechanical cabinet dryer (32\%), Bhat et al., (2014).

\section{Effect of drying methods on moisture content}

Santra and Jain (2012) carried out an experiment on convective drying of pomegranate arils to observe the effect of temperature on drying characteristics and physicochemical properties of pomegranate arils. The drying is done at $45^{\circ}, 50^{\circ}, 55^{\circ}$ and $60^{\circ} \mathrm{C}$ to reduce initial moisture content 377.09-442.68 percent $(\mathrm{db})$ to final moisture content of 5.7-9.62 percent (db) in 26.5, 17.5, 14 and $7.5 \mathrm{~h}$, respectively.

Bakshi et al., (2013) found that of all the drying treatments, oven drying $\left(42 \pm 2^{\circ} \mathrm{C}\right)$ for $16.5 \mathrm{~h}$ as well as drying at room temperature $\left(23 \pm 2^{\circ} \mathrm{C}\right)$ for $10-12$ days resulted in maximum loss of moisture from the fresh seeds of wild pomegranate i.e. $75.12 \%$. This was followed by vacuum drying for $13 \mathrm{~h}$ $\left(42 \pm 2^{\circ} \mathrm{C}\right)$ which resulted in $73.88 \%$ reduction in moisture content of the pomegranate seeds. The least reduction in moisture percentage of the fresh pomegranate seeds were observed in drying under poly-tent house where only $71.27 \%$ reduction in moisture content was recorded. Patil et al., (2013) found that the moisture content of anardana prepared from cabinet drying of pomegranate arils of cultivar Ganesh was $10.20 \%$ and Arakta was $10.50 \%$.

Bhat et al., (2014) conducted a study on the effect of drying methods and packaging on shelf life of dried wild pomegranate arils and found least content of moisture $(9 \%)$ in case of mechanical cabinet dryer and maximum moisture content was reported in case of sun drying $(10.72 \%)$.

Singh and Dayal (2015) dried pomegranate seeds (Bassien Seedless) under different conditions to produce value added product known as anardana. Mean values for moisture differed significantly in sun-dried (15.73\%) and cabinet-dried $(9.33 \%)$ samples. Organoleptic evaluation also gave overall mean score for cabinet dried samples were significantly higher (7.42) than sun dried samples (6.27). In general, drying was faster and quality was better in a cabinet dryer as compared to sun drying and statistically significant difference was noticed.

\section{Effect of drying methods on TSS}

Dadarao et al., (2010) conducted an experiment on effect of intermittent drying technique on quality of anardana. The TSS was found in the range of 32.16 to $36.98^{\circ} \mathrm{B}$.

Santra and Jain (2012) reported that maximum value of TSS of dried pomegranate arils were found to be 38.73 percent at $50^{\circ} \mathrm{C}$, followed by 37.63 percent at $45^{\circ} \mathrm{C}, 30.56$ percent at $60^{\circ} \mathrm{C}$ and 30.2 percent at $55^{\circ} \mathrm{C}$. An analysis of variance was carried out to study the effect of drying temperatures on TSS and which showed that temperature had nonsignificant effect at 5 percent level of significance.

The maximum TSS of dried pomegranate arils were found to be $39^{\circ} \mathrm{B}$ in case of mechanical cabinet dryer followed by solar 
cabinet dryer $\left(37.24^{\circ} \mathrm{B}\right)$ and sun drying $\left(37^{\circ} \mathrm{B}\right)$, Bhat et al., (2014).

\section{Effect of drying methods on acidity}

Aggarwal et al., (2010) reported maximum titratable acidity $(13.71 \%)$ in the arils dried in oven, whereas minimum titratable acidity of $12.40 \%$ was observed in the arils dried in open sun. Bhat et al., (2014) found maximum acidity of $13.72 \%$ in case of mechanical cabinet dryer followed by solar cabinet dryer $(13 \%)$ and sun drying (12.4\%) for anardana prepared from wild pomegrante.

Santra and Jain (2012) reported that maximum acid value of dried pomegranate arils were 0.605 percent at $45^{\circ} \mathrm{C}$, followed by 0.5 percent at $50^{\circ} \mathrm{C}, 0.409$ percent at $60^{\circ} \mathrm{C}$, and 0.395 percent at $55^{\circ} \mathrm{C}$.

Patil et al., (2013) carried out experiment to standardize the recipe for preparation of pomegranate anardana powder by using selected processing techniques and explore the prepared anardana powder with spices in mouth freshner. The mouth freshner was prepared by sun drying and cabinet drying. For acidity, sample of Ganesh and Arakta prepared by sun drying had highest acidity i.e. $1.4 \%$ and $1.6 \%$ respectively. For cabinet dried sample of Ganesh and Arkata cultivars acidity was $1.3 \%$ and $1.5 \%$ respectively.

Singh and Dayal (2015) found that anardana samples had 3.4\% more acidity in cabinet dried product than sun dried product irrespective of pretreatment used.

\section{Effect of drying methods on ascorbic acid}

Singh and Kingsly (2008) found that pomegranate arils dried at $55^{\circ} \mathrm{C}$ drying air temperature (drying time, $7 \mathrm{~h}$ ) retained desirable and acceptable quality parameters (titrable acidity $7.8 \%$, vitamin $\mathrm{C}$ as ascorbic acid $15.16 \mathrm{mg} / 100 \mathrm{~g}$ ) up to 180 days of storage.

Opera et al., (2009) studied physico-chemical properties, vitamin $\mathrm{C}$ content and antimicrobial properties of pomegranate fruit. A significant variation in vitamin $\mathrm{C}$ content was found among the five varieties of pomegranate studied, ranging from 52.8 to $72.0 \mathrm{mg} / 100 \mathrm{~g}$ fresh weight (fw) for arils and 76.8 to $118.4 \mathrm{mg} / 100 \mathrm{~g} \mathrm{fw}$ for peels. Irrespective of the variety of pomegranate, vitamin $\mathrm{C}$ content in the peel was significantly higher than the aril, with differences ranging from $24.4 \%$ to $97.0 \%$ depending on variety. Sun drying of fruit peel significantly enhanced vitamin $\mathrm{C}$ retention and antimicrobial effects in comparison with oven drying presumably due to lower rate of moisture removal associated with low temperature drying over longer duration in comparison with short time high temperature oven drying.

Data on the effect of drying modes on the ascorbic acid content of pomegranate arils shows that indirect solar dried arils had maximum (12.09 $\mathrm{mg} / 100 \mathrm{~g})$ ascorbic acid, whereas open sun dried arils had minimum $(7.85 \mathrm{mg} / 100 \mathrm{~g})$ ascorbic acid, Aggarwal et al., (2010).

Patil et al., (2013) carried out experiment to standardize the recipe for preparation of pomegranate anardana powder by using selected processing techniques and explore the prepared anardana powder with spices in mouth freshner. Ascorbic acid content was higher in cabinate dried sample $(6.7 \mathrm{mg} / 100 \mathrm{~g}$ and $7 \mathrm{mg} / 100 \mathrm{~g}$ ) for both cultivars. Whereas in sun dried samples of Ganesh and Arakta varieties ascorbic acid content was $6 \mathrm{mg} / 100 \mathrm{~g}$ and $6.5 \mathrm{mg} / 100 \mathrm{~g}$ respectively.

Bhat et al., (2014) found maximum ascorbic acid content of $12.1 \mathrm{mg} / 100 \mathrm{~g}$ in case of mechanical cabinet dryer followed by solar 
cabinet dryer $(9.4 \mathrm{mg} / 100 \mathrm{~g})$ and sun drying (7.85 mg/100g) for anardana prepared from wild pomegranate.

\section{Effect of drying methods on sugars}

Dadarao et al., (2010) conducted an experiment on effect of intermittent drying technique on quality of anardana. The reducing sugars, non reducing sugars, total sugars were found in the range of 12.72 to $16.21 \%, 1.86$ to $2.27 \%, 14.87$ to $18.14 \%$ respectively.

Based on the experiment conducted by Aggarwal et al., (2010), drying results of pomegranate reveal that reducing sugars were found maximum $(21.70 \%)$ in the arils dried in indirect solar dryer while minimum $(20.25 \%)$ was in open sun. The total sugars were found maximum $(24.18 \%)$ in arils dried in indirect solar dryer and minimum $(22.60 \%)$ in open sun.

Calin-Sanchez et al., (2013) reported that pomegranate aril sugars were more stable with softer drying conditions (low temperature and long time). Soft cabinet dryer conditions $\left(50^{\circ} \mathrm{C}\right)$ provided the best results, followed by $150 \mathrm{~min}$ CPD-VMFD (Combined drying consisted of convective pre-drying (CPD) at temperature $60^{\circ} \mathrm{C}$ for 90 or $150 \mathrm{~min}$, followed by vacuum microwave finish drying (VMFD) with microwave wattage of $360 \mathrm{~W}$ ). An increase in the product temperature caused important degradation of fructose and glucose (45\%), mainly because of Maillard and browning reactions was found in onion (Mota et al., 2010).

Patil et al., (2013) found that total sugars for anardana prepared from Ganesh and Arakta cultivar were $30.20 \%$ and $30.50 \%$ respectively. Reducing sugars content for Ganesh cultivar was $29 \%$ and $29.52 \%$ for Arakta variety. Nonreducing sugar content for Ganesh cultivar was $1.20 \%$ and $0.98 \%$ for Arakta variety.

Bhat et al., (2014) conducted a study on the effect of drying methods and packaging on shelf life of dried wild pomegranate arils and found maximum content of total sugars $(24.2 \%)$ and reducing sugars $(21.2 \%)$ in case of mechanical cabinet dryer followed by solar cabinet dryer and sun drying.

Singh and Dayal (2015) found the mean values for total sugars of pomegranate was higher in cabinet dried samples $(50.55 \%)$, which differed significantly from sun-dried samples $(47.72 \%)$.

\section{Effect of drying methods on anthocyanin content}

Singh and Sethi (2003) evaluated pysicochemical characteristics of seven pomegranate types in the production of anardana. Compared to fresh pomegranate arils, anardana demonstrated an increase in anthocyanin by weight. The authors felt that the increased levels of ascorbic acid may play a role in anthocyanin retention.

The levels of anthocyanin in anardana were studied by Jaiswal et al., (2010). Noting that polyphenoloxidase (PPO) may oxidize anthocyanin, drying effects on anthocyanin and PPO were studied. Sun drying was found to cause a greater loss of anthocyanin and a lesser reduction of PPO than oven drying in comparison to amounts present in fresh arils.

Bchir et al., (2012) investigated the drying of pomegranate seeds at $40^{\circ}, 50^{\circ}$ and $60^{\circ} \mathrm{C}$ with air velocity of $2 \mathrm{~m} / \mathrm{s}$. Both anthocyanin and total phenolic contents decreased when air drying temperature increased. The final product has 40 , $24,20 \mathrm{mg} / 100 \mathrm{~g} \mathrm{fm}$ of anthocyanin for drying temperatures of $40^{\circ}, 50^{\circ}$ and $60^{\circ} \mathrm{C}$ respectively. Bhat et al., (2014) conducted a study on the effect of drying methods and packaging on shelf life of dried wild pomegranate arils and found maximum anthocyanin content of 33.08 $\mathrm{mg} / 100 \mathrm{~g}$ in case of mechanical cabinet dryer followed by solar cabinet dryer (28.22 $\mathrm{mg} / 100 \mathrm{~g})$ and sun drying $(25.56 \mathrm{mg} / 100 \mathrm{~g})$.

Muharrem Golukcu (2015) reported highest contents of anthocyanin $(679.76 \mathrm{mg} / \mathrm{kg})$, in 
freeze dried sample, followed by vacuum, convective, and sun dried samples in descending order. The result of present study indicated that freeze drying was the best method for dried pomegranate aril production.

Singh and Dayal (2015) found anthocyanin content (as OD) differed significantly amongst different samples and was maximum (0.907) in steam-blanched cabinet-dried samples and minimum in sun-dried control samples.

Anthocyanin content was significantly affected by drying method, drying temperature and product thickness reported by Yilmaz et al., (2015).

\section{Effect of drying methods on phenols}

Bchir et al., (2012) investigated the drying of pomegranate seeds at $40^{\circ}, 50^{\circ}$ and $60^{\circ} \mathrm{C}$ with air velocity of $2 \mathrm{~m} / \mathrm{s}$. Total phenolic contents decreased when air-drying temperature increased. The radical diphenylpicril-hydrazyl activity showed the lowest antioxidant activity at $60^{\circ} \mathrm{C}$. The final product has 151,141 and 134 $\mathrm{mg}$ gallic acid equivalent/100g fresh matter (fm) of total phenolics for drying temperatures of $40^{\circ}, 50^{\circ}$ and $60^{\circ} \mathrm{C}$ respectively.

Bhat et al., (2014) found maximum phenols of $110.7 \mathrm{mg} / 100 \mathrm{~g}$ in case of mechanical cabinet dryer followed by solar cabinet dryer ( 96.8 $\mathrm{mg} / 100 \mathrm{~g}$ ) and sun drying $(90.5 \mathrm{mg} / 100 \mathrm{~g}$ ) for anardana prepared from wild pomegranate.

Muharrem Golukcu (2015) reported highest contents of phenolic matter $(5580 \mathrm{mg} / \mathrm{kg})$, in freeze dried sample of pomegranate, followed by vacuum, convective, and sun dried samples in descending order. The result of present study indicated that freeze drying was the best method for dried pomegranate aril production

In conclusion, the pomegranate fruit is considered as the suitable fruit for the processing and utilization due to its excellent flavour, colour, physicochemical constitution and therapeutic properties. It is referred as the
'Super fruit' due its high nutritional value, high antioxidant capacity and consumer appeal. The pomegranate processing and product diversification has played important role in the increased consumption and utilization of pomegranate. The fruit of pomegranate (Punicagranatum L.) is consumed fresh or it can be processed into juice, syrup, jam (anar rub), wine or anardana. These products are not yet popularized in large scale due to lack of the commercially viable processing technologies. Drying is the most widely employed method for preserving food materials. It is well known fact that drying methods, drying conditions and product thickness strongly influence the quality of final product. From an engineering point of view, drying operations should be handled by considering many aspects such as economy, final quality of product, consumer and preference. The efficiency of the process can be enhanced by optimizing drying conditions.

\section{References}

Aggarwal, R.K., Sharma, M.M. and Sharma, A.K. 2010. Indirect solar dryer with electric back up system for quality hill products. Natural Res., 1: 88-94.

Bakshi, P., Bhushan, B., Wali, V.K., Bakshi, M., Sharma, A. and Bhat, D.J. 2013. Standardization of drying method and organoleptic evaluation of wild pomegranate (anardana) seeds. World $J$. Agric. Sci., 9(5): 397-400.

Bchir, B., Besbes, S., Karoui, R., Attia, H., Paquot, M. and Blecker, C. 2012. Effect of air drying conditions on physicochemical properties of osmotically pretreated pomegranate seeds. Food Bioprocess Technol., 5: 1840-1852.

Bhat, M.M., Thakur, N.S.and Jindal, N. 2014. Studies on the effect of drying methods and packaging on quality and shelf life of dried wild pomegranate arils. Asian $J$. Dairy \& Food Res., 33(1): 18-24.

Calin-Sanchez, A., Figiel, A., Hernandez, F., Melgarejo, P., Lech, K. and CarbonellBarrachina, A.A. 2013. Chemical composition, antioxidant capacity, and 
sensory quality of pomegranate (Punicagranatum L.) arils and rind as affected by drying method. Food Bioprocess Technol., 6:1644-1654.

Dadarao, B.A., Pritam, B.S., Pandurang, B.H. and Annasaheb, M.B. 2010. Effect of intermittent drying technique on effective drying time for preparation of anardana. Intl. J. Agric. Eng., 3(1): 11-13.

Defilippi, G., Whitaker, B., Hess-Pierce, B., and Kader, A. 2006. Development and control of scald on wonderful pomegranates during long-term storage. Postharvest Biol. \& Technol., 41: 234-243.

Ertekin, C. and Yaldiz, O. 2010. Thin layer drying of sliced quash by forced convection. XVII th World Congress of the International Commission of Agricultural and Biosystems Engineering (CIGR. Qubec, Canada.

Gorjian, Sh., TavakkoliHashjin, T., Khoshtaghaza, M.H. and Nikbakht, A.M. 2011. Drying kinetics and quality of barbarry in a thin layer dryer. J. Agric. Part Sci. Technol., 13: 303-314.

Jaiswal, V., Dermarderosian, A. and Porter, J.R. 2010. Anthocyanins and polyphenol oxidase from dried arils of pomegranate (Punicagranatum L). Food Chem.,118: 11-16.

Mota, C.L., Luciano, C., Dias, A., Barroca, M.J. and Guine, R.P.F. 2010. Convective drying of onion: Kinetics and nutritional evaluation. Food Bioprod. Process, 88 (23): 115-123.

Muharrem Golukcu. 2015. The effects of drying methods, packaging atmosphere and storage time on dried pomegranate aril quality. Tar. Bil. Der. J. Agric. Sci., 21: 207-219.

Opera, L.O., Al-Ani, M.R. and Al-Shuaibi, Y.S. 2009. Physico-chemical properties, vitamin $\mathrm{C}$ content and antimicrobial properties of pomegranate fruit (Punicagranatum L). Food Bioprocess Technol., 2: 315-321.

Patil, P., Sayed, H.M., Joshi, A.A. and Jadhv, B.A. 2013. Standardization and preparation of value added product from pomegranate fruits (anardana and mouthfreshner. Int. J. Curr. Res., 5(8): 2056-2059.

Santra, I. and Jain, S.K. 2012. Studies on convective drying of pomegranate arils. Int. J. Proc. \& Post Harvest Technol., 3(2): 172-175.

Singh, D. and Dayal, H. 2015. Drying of pomegranate seeds (anardana) under different conditions.http://www.researchgate.net/p ublication/267405656.

Singh, D. and Sethi, V. 2003. Screening of pomegranate genotypes for the preparation of quality grade anardana. $J$. Food Sci. Technol., 40: 236-238.

Singh, D.B. and Kingsly, A.R.P. 2008. Effect of convective drying on quality of anardana. Indian J. Hort., 65(4): 413-416.

Yilmaz, F.M., Ksekkaya, S.Y., Vardin, H. and Karaaslan, M. 2015. The effects of drying conditions on moisture transfer and quality of pomegranate fruit leather (pestil. J. Saudi Society Agri. Sci., http://dx.doi.org/10.1016/j.jssas.2015.01. 003.

\section{How to cite this article:}

Monalisa Hota, D.S. Dahiya and Sonu Kumar. 2017. Effect of Various Drying Methods on Drying Time and Quality of Pomegranate (Punica granatum L.) Arils. Int.J.Curr.Microbiol.App.Sci. 6(4): 1711-1717. doi: https://doi.org/10.20546/ijcmas.2017.604.205 